\title{
АНАЛИЗА НА КРЕДИТНАТА ПОЛИТИКА И КРЕДИТНИОТ РИЗИК НА КОМЕРЦИЈАЛНА БАНКА ЗА ВРЕМЕ НА ПАНДЕМИЈАТА ВО 2020 ГОДИНА
}

\author{
Проф. д-р Марија Гогова Самоников ${ }^{1}$, Борче Ангов ${ }^{2}$ \\ 'Економски факултет, Универзитет „Гоце Делчев“, Штип \\ marija.gogova@ugd.edu.mk \\ ${ }^{2}$ Економски факултет, Универзитет „Гоце Делчев“, Штип \\ borce.083554@student.ugd.edu.mk
}

\begin{abstract}
Апстракт. Банката работи и располага со извори на средства како што се: депозити, штедни влогови, прибрани средства врз основа на издадени сопствени хартии од вредност, кредити и слично. Кредитната филозофија и култура на банката непосредно е преточена во нејзината формална кредитна политика, која треба да биде во согласност со долгорочните цели и стратегискиот план на банката.

Стратегијата за управување со кредитен ризик на Банката, ги дефинира основните цели и генерални насоки при преземање и управување со кредитниот ризик, интерно утврдување и оценка на потребната адекватност на капиталот, осврт на деловната стратегија на банката, евентуалните промени на деловната стратегија и прифатливото ниво на кредитен ризик на кое банката може да биде изложена во своето работење.
\end{abstract}

Клучни зборови: депозити, кредити, кредитна политика, кредитен ризик, адекватност на капиталот

\author{
CREDIT POLICY AND CREDIT RISK ANALYSIS OF A KOMERCIJALNA BANKA \\ DURING THE PANDEMIC IN 2020 \\ Assoc. Prof. Marija Gogova Samonikov ${ }^{1}$, Borce Angov ${ }^{2}$ \\ Faculty of Economics, Goce Delcev University, Stip, Macedonia \\ marija.gogova@ugd.edu.mk \\ Faculty of Economics, Goce Delcev University, Stip, Macedonia \\ borce.083554@student.ugd.edu.mk
}

\begin{abstract}
The Bank operates and has sources of funds such as: deposits, savings deposits, funds raised on the basis of issued own securities, loans and the like. The credit philosophy and culture of the bank is directly translated into its formal credit policy, which should be in line with the long-term goals and strategic plan of the bank.

The Credit Risk Management Strategy of the Bank defines the basic goals and general guidelines for undertaking and managing credit risk, internal determination and assessment of the required capital adequacy, review of the bank's business strategy, possible changes in the business strategy and the acceptable level of credit risk to which the bank may be exposed in its operations
\end{abstract}

Key words: deposits, loans, credit policy, credit risk, capital adequacy. 


\section{1. Вовед}

Кредитна политика претставува пишуван документ на банката во кој се определуваат основните принципи и правила на севкупниот процес на кредитирање. Таа претставува формален документ кој дава насоки кои понатаму треба да ги следат раководителите и службениците ангажирани во процесот на кредитирање. Видовите кредити кои ги нуди банката и под кои услови ги нуди, како и промената на условите кои настанале во 2020 година ќе бидат објаснети подетално во овој труд.

Банката има воспоставено информативен систем и аналитички техники кои овозможуваат мерење на кредитниот ризик. Мерењето на кредитниот ризик овозможува квантифицирање на ризикот на клиентите и лицата поврзани со нив, како и квантифицирање на ризикот на ниво на портфолио. Банката еднаш годишно врши стрес-тестирање, заради оцената на потенцијалното влијание на еден или повеќе внатрешни или надворешни фактори на ризик и на вредноста на средствата и обврските, односно врз нивото на сопствените средства и адекватноста на капиталот.

Процедурите за управување со кредитен ризик на Комерцијална банка АД Скопје содржат континуирано извршување на следниве интегрални процеси: идентификација, проценка, мерење, следење, контрола и намалување на кредитниот ризик. Ризик на земја претставува ризик од загуба поради изложеноста на Банката кон одделна земја, кој може да произлезе од економските, социјалните и политичките услови во земјата која се јавува во улога на должник. Посебна форма на ризик на земја претставува ризикот од трансфер кој произлегува од можните ограничувања при трансфер на средства од една земја во друга. Во критериумите за следење на кредитната способност на клиенти, странски лица, согласно процедурите за управување со кредитен ризик, Банката го зема предвид и ризикот на земјата каде се наоѓа седиштето, односно од каде доаѓаат тие клиенти. Сите овие работи ќе бидат подетално објаснети и ќе ни дадат јасна слика за состојбата на банката во услови на кризата во 2020 година.

\section{2. Комерцијална банка АД - Скопје}

Комерцијална банка АД Скопје е една од водечките банки во Република Северна Македонија која во своето долгогодишно постоење изгради имиџ на банка со традиција, доверба, сигурност, иновативност и силна домашна и меѓународна репутација. Како универзална македонска приватна независна банка, нуди широк асортиман на банкарски активности, почнувајќи од прибирање депозити, одобрување кредити на правни и физички лица, услуги во меѓународниот и домашниот платен промет, посредување во купопродажбата на девизи, хартии од вредност, форфетирање и слично. Преку широко распространетата мрежа на филијали, експозитури, банкомати и ПОС терминали, која постојано се зголемува, Банката е блиску и секогаш на услуга на крајните корисници. Деловната мрежа на Банката се состои од 11 филијали и 51 експозитури од кои 33 се лоцирани во Скопје. До денес на територијата на Република Северна Македонија има инсталирано 166 банкомати и голем број постерминали. Во функција на вршење брзи и ефикасни меѓународни услуги за своите клиенти, Банката има воспоставено кореспондентски односи со 515 банки од 71 земја, од кои контокорентски односи, ностро и лоро сметки, со 28 банки. Акционерскиот капитал на Банката се состои од 2.014.067 обични и приоритетни акции. Акциите на Комерцијална банка АД Скопје котираат на официјалниот пазар на Македонската берза за хартии од вредност и се вклучуваат во пресметката на Македонскиот берзански индекс, а од 2007 година истите котираат и во сегментот на супер котација. Комерцијална банка АД Скопје е член на Македонската банкарска асоцијација.

\section{3. Кредити за физички лица}

Комерцијална банка АД Скопје одобрува кредити на кредитоспособни физички лица државјани на Република Северна Македонија. Кредитите се исплатуваат во денари. При доспевање на последниот ануитет, возраста на кредитобарателот на треба да надминува 70 
години, освен за кредитите кои се целосно обезбедени со депониран депозит во Банката и за кредитите за пензионери. Исто така, при доспевање на последниот ануитет, возраста на жирантите не смее да надминува 62 години за жени и 64 години за мажи. На денот на поднесување на барањето за кредит, барателите на кредитот и жирантите не смеат да имаат доспеани, а неподмирени обврски кон Банката.

Барателите за кредит и жирантите е неопходно да имаат уредна кредитна историја во Банката и Кредитниот регистар на НБРСМ најмалку 6 месеци наназад, односно во роковите на достасаност да ги измируваат обврските по сите основи.

Барање за кредит може да се подигне и да се поднесе во Скопје - во Централата на Банката и во филијалите и експозитурите низ Републиката. Во зависност од намената на кредитот, средствата се исплаќаат на трансакциската сметка на кредитобарателот или, пак, на трансакциската сметка на продавачот. При користењето на кредитот се наплатува надомест за аплцирање и обработка на барањето за кредит, надомест за одобрување и администирање на кредит и интеркаларна камата за периодот од денот на користење на средствата до денот на ставање на кредитот во отплата по каматна стапка по која е одобрен кредитот.

Кредитите се отплаќаат во еднакви месечни ануитети кои доспеваат секој 16 (шеснаесетти) во месецот. За кредитите обезбедени со залог на подвижен и недвижен имот, потребна е Полиса за осигурување на имотот винкулирана во полза на Банката за целото времетраење на отплатата на кредитот.

Ненаменски кредити:

- Потрошувачки кредит до 1500000 денари;

- Потрошувачки кредит до 30000 евра со евро клаузула;

- Потрошувачки денарски кредит за пензионери до 100000 денари;

- Кредит врз основа на залог на депозит.

Наменски кредити:

- Наменски потрошувачки кредити преку трговец - Нептун.

Стабени кредити:

- Станбен кредит;

- Станбен кредит за купување недвижен имот, сопственост на Банката, лоциран во населба Ѓорче Петров, Јурија ${ }^{1}$.

Кредитот е наменет за кредитоспособни физички лица во редовен работен однос на неопределено време во јавната администрација, финансиски институции или дипломатски странски претставништва во Република Северна Македонија или во фирми прифатливи за Банката, кои примаат плата на трансакциска сметка во Комерцијална банка АД Скопје во износ повисок од 14500 денари. Доколку кредитобарателот ги исполнува критериумите на Банката, кредитот се одобрува во рок од 24 часа по комплетирање на документацијата.

Кредитот изнесува од 1000 000,00 до 1500 000,00 денари, додека рокот за отплата е од 12 до 95 месеци. Исто така постои можност за грејс период од 6 месеци. За времетраењето на грејс периодот се пресметува интеркаларна камата во висина на каматната стапка на кредитот.

Како критериуми што треба да ги исполнуваат кредитобарателите се сметаат:

- Месечни примања во износ повисок од 14500 денари;

- Месечниот ануитет треба да се покрие со една половина од месечните нето-примања на кредитобарателот;

- Кредитобарателот да биде корисник на електронското банкарство;

\footnotetext{
1 https://www.kb.com.mk/Default.aspx?sel=2310\&lang=1\&uc=1
} 
- При доспевање на последниот ануитет, возраста на кредитобарателот не треба да надминува 70 години.

Трошоците што ги имаат кредитобарателите додека да им биде одобрен кредитот се следните:

- 2 000,00 денари надомест за одобрување и администрирање на кредитот;

- 300,00 денари за аплицирање и обработка на кредитот;

- Трошоци за интеркаларна камата (интеркаларна камата се пресметува од денот на користење на средствата до денот на ставање на кредитот во отплата по каматна стапка еднаква на каматната стапка на кредитот);

- Трошоци за меница.

Како обезбедување на кредитот се користи:

- Меница со менична изјава чија вредност го покрива одобрениот кредит и камата, потпишана од кредитобарателот;

- Траен налог за наплата на месечните ануитети од трансакциска сметка на корисникот на кредитот;

- Административна забрана од плата;

- По извршената кредитна анализа, Банката може да побара дополнително обезбедување - жирант.

Номиналната каматна стапка изнесува $5 \%$ годишна, фиксна за првите 2 години, и каматна стапка од $6,15 \%$ годишна, променлива за остатокот на периодот на отплата. Годишната стапка на вкупни трошоци е $5,81 \%$ и врз нејзината висина влијае рокот на враќање на кредитот, износот на кредитот, износот на трошоците за кредитот што се вклучени во пресметката и висината на номиналната каматна стапка.

Документите кои треба да ги поднесе кредитобарателот до кредитниот референт се следниве:

- Барање за кредит;

- Копија од валидна лична карта;

- За вработени во приватни фирми прифатливи за Банката - образец ПП53 (Декларација за прием од УЈП) за последните 3 месеци и солвентност на жиро сметка од банката во која се депоненти. Доколку се депоненти на Комерцијална банка АД - Скопје не е потребна солвентност, а за примателите на плата во Комерцијална банка не се потребни ПП53 обрасци;

- $\mathrm{M} 1 / \mathrm{M} 2$ образец.

Максималниот рок на искористување на кредитот е 60 дена од денот на одобрување, а средствата се исплаќаат на трансакциската сметка на кредитокорисникот ${ }^{2}$.

3.1 Промена на договорните услови за кредитните производи поради кризата Ковид 19

Со цел ублажување на последиците од пандемијата на КОВИД-19, Комерцијална банка АД Скопје ги променила договорните услови за кредитните производи.

Кога станува збор за грејс периодот, банката одобрила шестмесечни ануитети во период од април до септември 2020 година во кој период не достасувале ануитети по кредитот и крајниот рок за отплата се одложил за шест месеци. За цело времетраење на грејс периодот, банката пресметувала камата по каматна стапка предвидена во Договорот за кредит. По истек на предвидениот грејс период од шест месеци, каматата пресметана во грејс периодот се додала на кредитното салдо на кредитот и рамномерно се распоредила за

\footnotetext{
2 https://www.kb.com.mk/Default.aspx?sel=2391\&lang=1\&uc=1\&par=0
} 
наплата во ануитетите согласно новиот амортизационен план. Банката не пресметувала камата на капитализираната камата. Трајниот налог за наплата на обврските по кредитот бил ставен во мирување.

Од октомври 2020 година Банката направила ново продолжување на олеснетите услови за сервисирање на обврските, врз основа на селективен пристап за најпогодените субјекти, а за останатите клиенти продолжило редовното достасување на ануитети по кредитот, за коешто банката го известува корисникот на кредитот за новиот износ на ануитетот на начин предвиден во Договорот за кредит. Капитализираната камата добила приоритет на наплата пред главнината по кредитот, така што Банката од извршените уплати и наплатата ги затвора обврските по рочност на нивното достасување по следниот редослед: трошоци по кредит, камати, капитализирана камата и главнина по кредитот. Овој редослед на засметување се применувал и во случај на предвремена уплата на недостасаниот дел од кредитот³ ${ }^{3}$

\section{4. Кредити за правни лица}

Комерцијална банка АД Скопје посебно внимание обрнува на кредитната поддршка на правни лица.

\section{Процедура на одобрување}

По поднесување на барањето за кредит, Банката прави формален преглед дали е комплетна документацијата. Доколку документацијата е комплетна, барањето се обработува, при што се оценува бонитетот на барателот и планираната зделка за која се наменети средствата. Информациите за комитентот, подносител на барањето за кредит, Банката ги обезбедува од самиот комитент и од сопствени извори. Комитентот во разумен рок е информиран за поднесеното барање со известување дали бараниот кредит е одобрен или не.

Рок на отплата

Максималниот рок на отплата на кредитите може да биде до 10 години со вклучен грејс период од 2 години.

Провизии и останати трошоци

На искористениот износ на кредит, Банката наплатува еднократен надомест во висина од $0.05 \%$ до $1.5 \%$, во зависност од видот на кредитот, рокот на враќање на кредитот и изворот на средствата за кредитот.

\section{Потребна документација}

Барањето за кредит треба да ги содржи следните елементи:

- Полн назив на претпријатието;

- Адреса на претпријатието;

- Основачи и органи на управување;

- Доколку основачите се основачи во други друштва, да се наведат друштвата и процентот на учество во капиталот на друштвото;

- Управување во други друштва;

\footnotetext{
${ }^{3}$ https://www.kb.com.mk/Default.aspx?sel=2370\&lang=1\&uc=1
} 
- Шифра на дејност;

- Матичен број;

- Број на жиро-сметка/сметки;

- Деловна банка/банки;

- Намена и износ на бараниот кредит со образложение;

- Основна дејност;

- Организациска поставеност;

- Број на вработени и квалификациона структура;

- Техничко-технолошка опременост и искористеност на капацитетите;

- Асортиман на производство прикажан во физички и во вредносен обем;

- Склучени договори за работа;

- Спецификација на поголеми купувачи и добавувачи;

- Извештај за состојбата на залихите;

- Задолженост во други банки и финансиски организации;

- Преземени идни обврски (акредитиви, гаранции и сл.);

- Опис на понуденото обезбедување;

- Извори на отплата (CASH FLOW);

- Склучени извозни договори и очекувани девизни приливи по извршен извоз;

- План на девизни приливи и одливи.

За долгорочните кредити е потребно доставување на инвестициона програма со финансиски превидувања за периодот на отплата на кредитот ${ }^{4}$.

Кредит за поддршка на микро, мали и средни трговски друштва

Кредитот е наменет за микро, мали и средни трговски друштва, со седиште во Република Северна Македонија.

Намената на кредитот е набавка на основни и/или обртни средства, до 30 \% од вкупно одобрениот кредит може да биде наменет за обртен капитал. Кога станува збор за земјата на набавка на средствата не постои ограничување, односно опремата може да се набави од земјата и странство.

Максималниот износ на одобрениот кредит може да биде до 300000 евра, а рокот на отплата е до 3 години за финансирање на обртни средства, односно до 10 години за финансирање на основни средства, додека грејс периодот изнесува максимум 12 месеци.

Каматната стапка изнесува до 5 \% годишно, фиксно. А, кога станува збор за провизијата, се пресметува $1 \%$ еднократна провизија пред користење, во денари.

За обезбедување на кредитот се користат вообичаени инструменти за обезбедување согласно Кредитната политика на Банката (хипотека на недвижен имот, залог на подвижни предмети, меници и др.)

Со кредитот се финансира до 80 \% од пресметковната вредност на проектот, а остатокот од минимум $20 \%$ е сопствено учество на корисникот на кредит 5 .

\section{1 Промена на договорните услови за кредитни картички за правни лица поради кризата Ковид 19}

Оваа промена се однесувала на сите правни лица, корисници на кредитни картички издадени од Банката, кои на 29.02.2020 година биле класифицирани во категорија на ризик буква А, Б или В и немаат статус на нефункционална кредитна изложеност.

\footnotetext{
4 https://www.kb.com.mk/Default.aspx?sel=3210\&lang=1\&uc=1\#2

5 https://www.kb.com.mk/Default.aspx?sel=3231\&lang=1\&uc=1\&par=0
} 
АНАЛИЗА НА КРЕДИТНАТА ПОЛИТИКА И КРЕДИТНИОТ РИЗИК НА КОМЕРЦИЈАЛНА БАНКА ЗА ВРЕМЕ НА ПАНДЕМИЈАТА ВО 2020 ГОДИНА

Во периодот април до септември 2020 година, односно во период од шест месеци износот на месечниот минимум за плаќање изнесувал $0 \%$ од искористениот кредитен лимит на крајот од месецот, односно не достасувал месечниот износ за плаќање. Износот на одобрениот кредитен лимит не се намалувал до 30.09.2020 година.

Во грејс периодот Банката пресметувала и наплатувала камата согласно одредбите предвидени во Договорот за користење кредитна картичка. За износот на пресметана и наплатена камата и редовни месечни надоместоци предвидени во Договорот, Банката го зголемила износот на кредитен лимит и сметката немало да има третман на надминат кредитен лимит. Во грејс периодот, трајниот налог за наплата на обврските по кредитната картичка, бил ставен во мирување. Почнувајќи од 01.10.2020 година, како основа за пресметката на минимален износ за плаќање предвиден во Договорот за кредитна картичка, се користел долгот на сметката со состојба 30.09.2020 година. За време на грејс периодот корисниците имале право самостојно да вршат уплати на кредитната картичка. Сите уплати на сметката на кредитната картичка извршени во грејс периодот, се евидентирале како приливи на сметката и ќе биле на располагање на корисникот за користење со картичката ${ }^{6}$.

\section{5. Кредитен ризик на Комерцијална банка за време на пандемијата во 2020 година}

Во рамки на управувањето со кредитниот ризик, во текот на 2020 година биле преземени интензивни активности за усогласување со донесените прописи во вонредни услови. Како резултат на донесената Одлука за изменување и дополнување на Одлуката за методологијата за управување со кредитниот ризик на Народната банка на Република Северна Македонија и Уредбата со законска сила за начинот на промената на договорните услови на кредитните изложености кај банките и штедилниците, со цел ублажување на последиците од пандемијата со Ковид-19, била извршена промена на критериумот за премин во нефункционално побарување од 90 на 150 дена и овозможени биле измени во договорните услови за одобрените кредитни изложености кои немале третман на реструктурирање, односно продолжување на рокот на достасување на одобрените кредити, како и на дозволените пречекорувања на кредитини картички и тековни сметки.

За кредитните изложености кон физички лица Банката објавила јавна понуда за можностите кои биле понудени во вонредни услови како прв сет мерки, така и за втор сет мерки за клиентите кои исполнуваат определени услови, додека за правните лица бил применет индивидуален пристап за олеснување на договорните услови. Вкупно, со првиот сет мерки била опфатена изложеност од 25 080,2 милиони денари, што претставува 17 $\%$ од вкупната изложеност на Банката со состојба на 31.12.2020 година. Со вториот сет мерки била опфатена изложеност од 7 174,0 милиони денари, односно 5 \% од вкупната изложеност со состојба на 31.12.2020 година.

Анализата на ефектот на кризата во секторите кај правните лица ѝ овозможила на Банката да ги идентификува секторите кај кои бил забележан поизразен негативен ефект во работењето. Како најпогодени сектори се идентификувани објекти за сместување, односно хотелските капацитети и сервисните дејности со храна, транспортот и складирањето и преработувачката индустрија ${ }^{7}$.

\footnotetext{
${ }^{6}$ https://www.kb.com.mk/Default.aspx?sel=3570\&lang=1\&uc=1

7 Ничева, М. и Ставрев, Д., Годишен извештај 2020, Комерцијална банка АД Скопје, 30-31.
} 
Табела 1 Квалитет на вкупната изложеност на банката ${ }^{8}$

\begin{tabular}{|c|c|c|}
\hline Ризична категорија & $\mathbf{3 1 . 1 2 . 2 0 2 0}$ & $\mathbf{3 1 . 1 2 . 2 0 1 9}$ \\
\hline А & $90,4 \%$ & $91,2 \%$ \\
\hline Б & $5,0 \%$ & $5,2 \%$ \\
\hline Б & $2,9 \%$ & $1,0 \%$ \\
\hline Г И Д & $1,7 \%$ & $2,6 \%$ \\
\hline
\end{tabular}

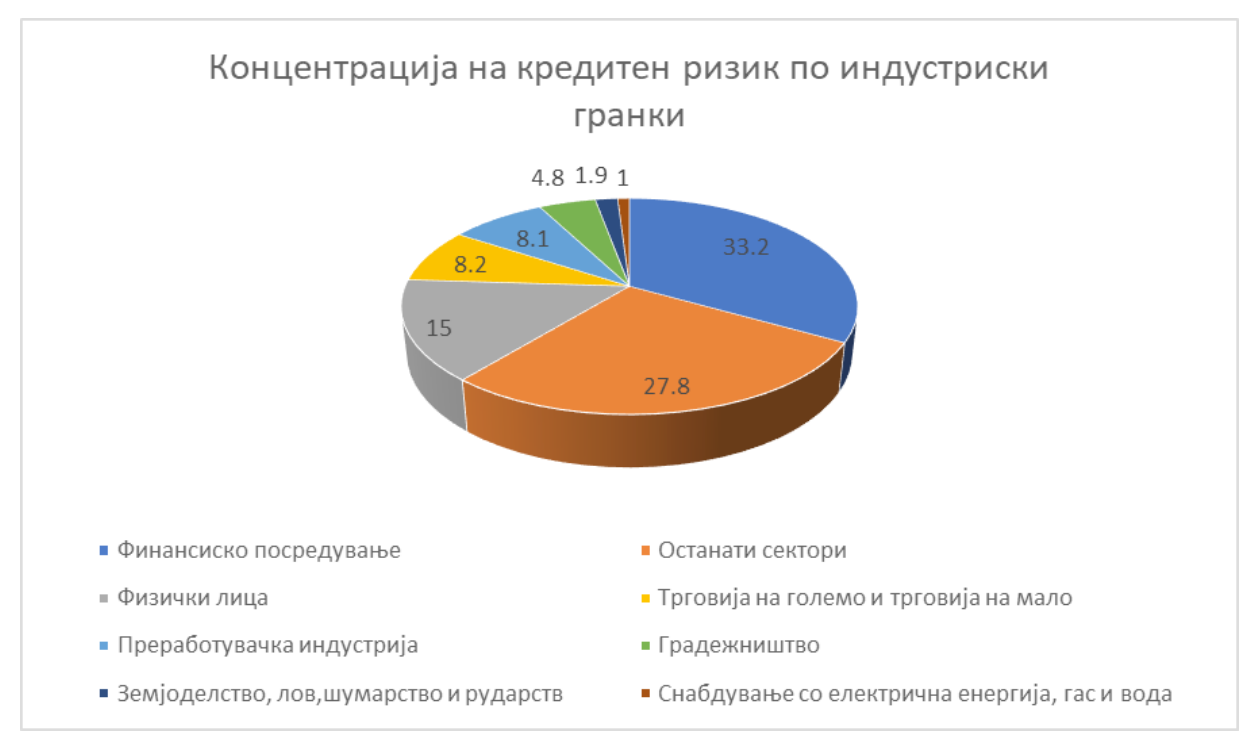

Слика 1: Концентрација на кредитниот ризик по индустриски гранки9

\section{Концентрација на кредитниот ризик по географска локација}

Вредноста на вкупната кредитна изложеност по географска локација на должниците покажува највисока концентрација во Република Северна Македонија која што на 31.12.2020 година изнесувала 89,59 \%, од вкупната изложеност, додека во 2019 година изнесувала $88,27 \%$.

Изложеноста кон должниците од земјите членки на Европската унија изнесувала 6,56 \% на 31.12.2020 година, додека во 2019 година била 7,08 \%.

Изложеноста кон должниците на останатите земји од Европа и земјите членки на ОЕЦД изнесувала 3,85 \%, од вкупната изложеност на кредитен ризик на 31.12.2020 година, додека во 2019 година таа била 4,65 \%.

Достасаната изложеност за која Група не евидентирала исправка на вредноста изнесувала 61592 денари на 31.12.2020 година, а во 2019 година износот бил 210661 денари и се однесува на побарувањата достасани за 30 дена како и вонбилансни изложености во износ од 10949 денари на 31.12.2020 година, додека во 2019 година изнесувала 11201 денари.

Износот на недостасани побарувања за која Групата не евидентирала исправка на вредноста на 31.12.2020 година износот бил 59947.872 денари, а на 31.12.2019 година изнесувале 44801.945 денари. Во најголем дел се однесувала на изложеност на клиенти кои имаат првокласно обезбедување, односно паричен депозит и изложености за кои согласно со регулативата на Народната банка за методологијата за утврдување на адекватноста на капиталот се применува пондер на ризичност $0 \%{ }^{10}$.

\footnotetext{
${ }^{8}$ Ничева, М. и Ставрев, Д., Годишен извештај 2020, Комерцијална банка АД Скопје, 31.

${ }^{9}$ Ничева, М. и Ставрев, Д., Годишен извештај 2020, Комерцијална банка АД Скопје, стр. 32.
}

10 Комерцијална банка АД Скопје, Извештај на независниот ревизор и Консолидирани финансиски извештаи за годината што завршува на 31 декември 2020 година, стр. 48. 


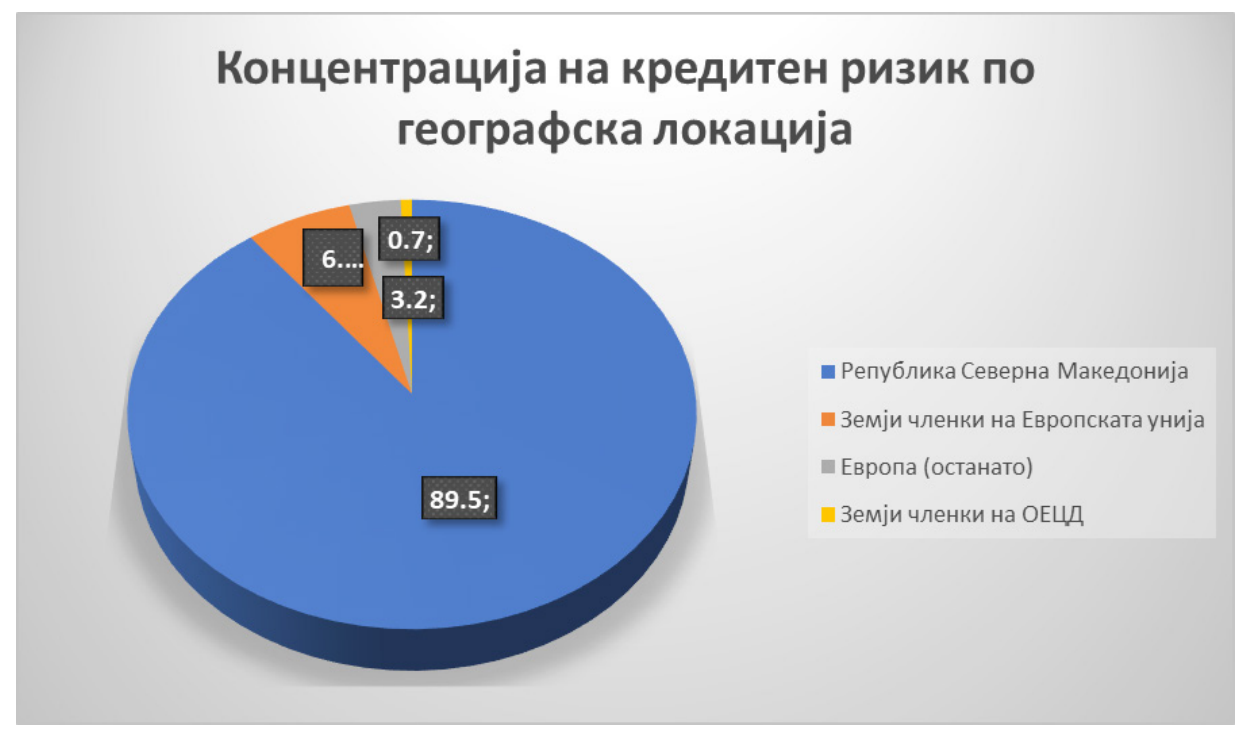

Слика 2: Концентрација на кредитниот ризик по географска локација ${ }^{11}$

Врз основа на сето ова може да заклучиме дека Комерцијална банка АД Скопје добро се справува со актуелната криза преку нудење нови и попогодни услови за нејзините коминтенти со цел да им овозможи лесно справување со нивните обврски кон банката.

Комерцијална банка АД Скопје била прогласена за „Банка на годината во 2020 година“ во Република Северна Македонија од страна на престижниот финансиски магазин „Тhе Banker“. Наградата се доделува на банките кои покажале успешни финансиски резултати, успех во целокупната деловна стратегија со кој оствариле конкурентска предност, унапредување и развој на технологијата и на производите и услугите, како и соодветен одговор на кризата наметната од КОВИД-19. Постигнатиот финансиски резултат на банката во првите девет месеци од 2020 година, изнесувал 1 310,6 милиони денари, што е 0,8 \% повеќе во однос на добивката од 2019 година во истиот период и 89,1 \% од планираната добивка.

Остварените резултати секоја година ја рангираат Комерцијална банка во самиот врв на македонскиот банкарски сектор. Растот на кредитите и побарувањата од круги комитенти со споменатиот датум изнесувал $9,9 \%$, додека во делот на депозитите изнесувал 6,9 \%.

Банката ја гради својата лидерска позиција преку професионално, стручно и одговорно работење, континуирана финансиска поддршка за раст и развој на компаниите, и понуда на иновативни производи и услуги креирани согласно потребите на клиентите. Влијанието врз клиентите на КОВИД-19, најмногу се одразило врз корпоративниот сектор, каде се оневозможила исплатата на плати, што посредно се рефлектирало и на секторот население. Несаканите економски ефекти од КОВИД-19 биле ублажени преку воведените промени во отплатата на кредитните обврски на граѓаните и на компаниите. Од 01.10.2020 направила ново продолжување на олеснетите услови за сервисирање на обврските, при што тоа било направено врз основа на селективен пристап за најпогодените субјекти, физички и правни лица. Комерцијална банка, исто така, понудила и потрошувачки кредити со променети услови и нови корпоративни кредити за покривање на потребите за ликвидност на компаниите.

Инвестициите во технолошката инфраструктура на Банката го довеле дигиталниот свет на банкарски услуги сѐ поблиску до граѓаните и компаниите. Споредено со истиот период претходната година, може да се забележи значајна промена во учеството на електронски наспроти хартиени налози во платниот промет од 3 процентни поени во полза

\footnotetext{
${ }^{11}$ Ничева, М. и Ставрев, Д., Годишен извештај 2020, Комерцијална банка АД Скопје, 32.
} 
на електронските трансфери. Во истиот извештаен период, плаќањата преку мобилен телефон се зголемени за над 50 \%, а вкупните плаќања со платежни картички за $11 \%$.

Сите овие аргументи ни даваат јасна слика дека Комерцијална банка АД Скопје има висока општествена одговорност и флексибилна поддршка на клиентите за заедничко справување со последиците од пандемијата.

\section{Користена литература:}

1. Давчев, Љ. (2014). Инвестициско банкарство, Економски факултет, Универзитет „Гоце Делчев“" - Штип;

2. Маџарова, В. (2011). Кредитна политика, Економски факултет, Универзитет „Гоце Делчев“" - Штип;

3. Петревски, Г. (2008). Управување со банките, Универзитет „Св. Кирил и Методиј“, Економски факултет - Скопје;

4. Самоников, Г. М. (2020). Основи на финансии, Економски факултет, Универзитет „Гоце Делчев“ - Штип;

5. Самоников, Г. М. (2020). Современи финансии интерен материјал, Економски факултет, Универзитет „Гоце Делчев“- Штип;

6. Самоников, Г. М. (2018). Финансиска регулација, скрипта, Економски факултет, Универзитет „Гоце Делчев“ - Штип;

7. Свртинов, Г. В. (2020). Управување со ризици, скрипта, Економски факултет, Универзитет „Гоце Делчев“ - Штип;

8. Темелков, 3. (2019). Банкарско работење, скрипта, Факултет за туризам и бизнис логистика, Универзитет „Гоце Делчев“ - Штип;

9. Трпески, Љ. (2009). Банкарство и банкарско работење прво издание, Скопје;

10. Фотов, Р. и Фотова, Ч. К. (2015). Финансиски менаџмент, Економски факултет, Универзитет „Гоце Делчев“- Штип;

11. Фотов, Р. и Самоников, Г. М. (2015). Финансиски пазари и институции, Економски факултет, Универзитет „Гоце Делчев“- Штип;

12. Фотов, Р. (2013). Основи на финансии, Економски факултет, Универзитет „Гоце Делчев" - Штип;

13. Ничева, М. и Ставрев, Д., Годишен извештај 2020, Комерцијална банка АД Скопје;

14. Комерцијална банка АД Скопје, Извештај на независниот ревизор и Консолидирани финансиски извештаи за годината што завршува на 31 декември 2020 година;

15. https://www.kb.com.mk/Default.aspx?sel=1100\&lang=1\&uc $=1$

16. https://www.kb.com.mk/Default.aspx?sel=2310\&lang=1\&uc=1

17. https://www.kb.com.mk/Default.aspx? sel $=2391 \&$ lang $=1 \& u c=1 \& p a r=0$

18. https://www.kb.com.mk/Default.aspx? sel=2370\&lang $=1 \& u c=1$

19. https://www.kb.com.mk/Default.aspx?sel $=3210 \&$ lang $=1 \& u c=1 \# 2$

20. https://www.kb.com.mk/Default.aspx? sel $=3231 \&$ lang $=1 \& u c=1 \& p a r=0$

21. https://www.kb.com.mk/Default.aspx?sel=3570\&lang=1\&uc=1 